\title{
PROTON THERAPY FOR RE-IRRADIATION OF PEDIATRIC DIFFUSE BRAIN STEM TUMORS
}

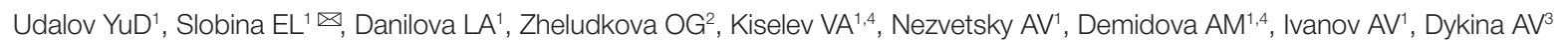

${ }^{1}$ Federal Research and Clinical Center for Medical Radiology and Oncology of FMBA, Dimitrovgrad, Russia

${ }^{2}$ Voyno-Yasenetsky Research and Practical Center of Specialized Medical Care for Children, Moscow, Russia

${ }^{3}$ Russian Scientific Center for Roentgenoradiology, Moscow, Russia

${ }^{4}$ Dimitrovgrad Institute of Engineering and Technology of the National Research Nuclear University MEPhl, Dimitrovgrad, Russia

Currently, there is no cure for pediatric diffuse brain stem (BS) tumors. Radiotherapy, including proton therapy, is an important component of combination treatment for this cancer, especially in children with a complicated medical history. The article addresses the issues of therapy for pediatric BS tumors and reports the use of proton re-irradiation in a 9-year-old boy with unverified diffuse BS tumor. Proton re-irradiation is an effective treatment option that can sustain and improve the quality of life and prolong survival in children with diffuse BS tumors.

Keywords: diffuse brainstem tumor, re-irradiation, proton therapy

Funding: the article is part of the research project on Creating and maintaining a database of patients undergoing proton therapy for cancer for FMBA, Russia and was conducted under the State Assignment 388-00141-21-00 dated December 24, 2020.

Author contribution: Udalov YuD initiated the publication; Slobina EL delivered medical care and photon irradiation at the first stage of treatment and was responsible for writing the manuscript; Danilova LA chairman of the medical council that proposed treatment strategy; Zheludkova OG pediatric oncologist, that proposed treatment strategy and supervised all stages of treatment; Kiselev VA calculated total radiation doses and their temporal and spatial distribution at all treatment stages; Nezvetsky AV delivered medical care and proton irradiation at the second stage of treatment; Demidova AM planned proton therapy; Ivanov AV responsible for the anesthetic support of the patient's radiation therapy sessions; Dykina AV planned photon therapy.

$\bowtie$ Correspondence should be addressed: Elena L. Slobina

Kurchatova, 5V, Dimitrovgrad, 433507, Russia; slobina@fvcmrmail.ru

Received: 04.10.2021 Accepted: 12.11.2021 Published online: 07.12.2021

DOI: $10.47183 /$ mes.2021.039

\section{ВОЗМОЖНОСТИ ПРОТОННОЙ ТЕРАПИИ ПРИ ПОВТОРНОМ ОБЛУЧЕНИИ ДИФФУЗНОЙ ОПУХОЛИ СТВОЛА МОЗГА У ДЕТЕЙ}

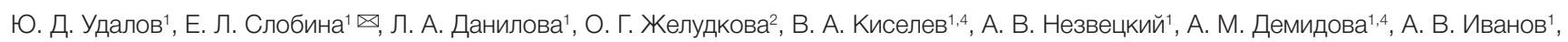
А. В. Дыкина ${ }^{3}$

1 Федеральный научно-клинический центр медицинской радиологии и онкологии Федерального медико-биологического агентства, Димитровград, Россия

2 Научно-практический центр специализированной медицинской помощи детям имени В. Ф. Войно-Ясенецкого, Москва, Россия

${ }^{3}$ Российский научный центр рентгенорадиологии, Москва, Россия

${ }^{4}$ Димитровградский инженерно-технологический институт национального исследовательского ядерного университета «МИФИ», Димитровград, Россия

В настоящее время полное и стойкое излечение диффузных опухолей ствола мозга (СМ) у детей невозможно. Современная лучевая терапия диффузных опухолей СМ, включая терапию протонами, является важным элементом комплексного лечения, особенно у пациентов детского возраста с отягощенным анамнезом. В статье обсуждены вопросы специального противоопухолевого лечения диффузных опухолей ствола мозга у детей и представлен сложный клинический случай повторной лучевой терапии рецидива неверифицированной диффузной опухоли СМ у девятилетнего мальчика с применением протонной терапии (ПТ). Проведение повторной лучевой терапии протонами при диффузных опухолях СМ является эффективным методом сохранения, а иногда улучшения качества жизни у детей и увеличения ее продолжительности.

Ключевые слова: диффузная опухоль ствола головного мозга, повторная лучевая терапия, протонная терапия

Финансирование: публикация подготовлена в рамках НИР «Создание и сопровождение базы данных пациентов, получавших протонную терапию по поводу онкологических заболеваний в системе ФМБА России" в соответствии с Государственным заданием № 388-00141-21-00 от 24.12.2020.

Вклад авторов: Ю. Д. Удалов - инициатор публикации; Е. Л. Слобина - ответственный автор за написание статьи, лечение пациента на первом этапе специального противоопухолевого лечения; Л. А. Данилова - председатель консилиума по определению тактики лечения пациентов, определение тактики лечения пациента; О. Г. Желудкова — определение тактики лечения пациента, общее курирование лечения пациента; В. А. Киселев расчеты суммарных очаговых доз на всех этапах лучевого лечения и их распределение в пространстве и времени; А. В. Незвецкий - проведение противоопухолевого лечения с применением протонной терапии; А. М. Демидова, А. В. Дыкина — планирование протонной терапии; А. В. Иванов проведение лучевой терапии.

$\bowtie$ Для корреспонденции: Елена Леонидовна Слобина ул. Курчатова, д. 5В, г. Димитровград, 433507, Россия; slobina@fvcmrmail.ru

Статья получена: 04.10.2021 Статья принята к печати: 12.11.2021 Опубликована онлайн: 07.12.2021

DOI: $10.47183 /$ mes.2021.039

Pediatric diffuse brain stem (BS) tumors remain an unsolved therapeutic challenge. Their radical surgical resection is impossible due to the unique anatomy of this brain structure that controls vital body functions. According to autopsy reports, most of BS tumors are ependymomas and astrocytomas of different grades of malignancy [1]. Currently there are no effective medication therapies against childhood BS tumors [2-6]. The main treatment option is radiotherapy (RT): it temporarily delays tumor progression, sustains or improves the patient's quality of life and neurological status, and prolongs survival $[7,8]$. However, RT offers no cure despite the advanced instrumentation, the vast variety of radiation sources and the ongoing development of new treatment planning techniques and therapeutic strategies guided by radiobiological and molecular prognostic factors [8-12]. Therapy for childhood BS tumors provides a temporary effect which depends on the degree of malignancy and the aggressiveness of the tumor. In light of this, development of novel therapies targeting the genetic machinery of the tumor, as well as cancer vaccines, holds promise for the therapy of BS tumors [13]. Local recurrence and, less frequently, metastatic spread are the primary obstacles to treatment success. Re-irradiation is one of 
the very few therapeutic options for progressive or recurrent BS tumors [14-16]. Therapy against childhood BS tumors seeks to sustain or improve the quality of life and prolong survival. This goal can be achieved through using state-of-the-art RT, including proton RT $[17,18]$.

\section{Clinical case}

Below we report a clinical case of a pediatric patient with a recurrent diffuse BS tumor treated with re-irradiation (proton therapy) at the Federal Research and Clinical Center for Medical Radiology and Oncology (FMBA, Dimitrovgrad, Russia) [19]

Patient G, 9 years, was first diagnosed with unverified diffuse BS glioma (C71.7) in July, 2019. The patient suffered a relapse in December 2020. Stabilization was achieved till September 2021. The patient's condition was complicated by obstructive hydrocephalus.

At the age of 9 (prior to diagnosis), the patient started complaining of headaches, gait disturbance, squinting, and morning vomiting. Brain MRI performed on July 10, 2019 was suggestive of a diffuse BS neoplasm $58 \times 34 \times 40 \mathrm{~mm}$ in size spreading to the right pons, the right peduncle and the hemisphere of the cerebellum (Fig. 1).

On July 24, 2019, the patient received a ventriculoperitoneal shunt (VPS).

From August 2 to September 12, 2019, the patient was undergoing 3D conformal photon RT at the total dose of 54 Gy delivered in 1.8 Gy per fraction (Fig. 2).

Two months after the initial RT course, brain MRI performed on October 31, 2019 showed no contrast enhancement, suggesting tumor regression (Fig. 3).

${ }^{11} \mathrm{C}$-methionine PET/CT conducted on November 5, 2019 detected no signs of metabolic tumor activity in the brain structures.

The patient was followed up for 15 months.

Then, brain MRI (December 8, 2020) and ${ }^{11} \mathrm{C}$-methionine PET/CT (January 11, 2021) were suggestive of diffuse changes in BS and increased radiopharmaceutical uptake in the pons (uptake ratio: 2.2); the lesion size on PET/CT was $21 \times 15 \times 22 \mathrm{~mm}$, which was consistent with MRI findings (Fig. 4).

Considering the medical history of the patient, time elapsed from the first RT course and the fact of tumor recurrence, proton re-irradiation was recommended by the case conference panel.

Optimized intensity-modulated proton therapy [17] for the metabolically active recurrent lesion was delivered to the patient at the Federal Research and Clinical Center for Medical Radiology and Oncology from January 26, 2021 to March 5, 2021. Dose planning was based on ${ }^{11} \mathrm{C}$-methionine PET/CT findings. A ProteusPlus 235 system (IBA; Belgium) was used for irradiation. Therapy was delivered in 28 daily fractions (1.8 Gy or per fraction); the total dose was 50.4 Gy. Glucocorticoids were administered concomitantly to reduce cerebral edema. PTV dose coverage D98\% was 98\% Gy of the prescription dose (Fig. 5). No adverse effects were observed. By the end of the treatment course, the tumor had regressed completely.

The patient was discharged home. Further follow-up with a local pediatric oncologist and other involved specialists was recommended. As of September 2021 (6 months after reirradiation), there had been no signs of recurrent tumor growth, neurologic deficit or VPS dysfunction.

\section{Discussion}

Diffuse intrinsic pontine glioma (DIPG) is the primary cause of pediatric mortality from CNS malignancies. This aggressive tumor makes up $75-80 \%$ of pediatric BS malignancies and $10 \%$ of all pediatric CNS tumors [20-22]. Prognosis for DIPG is much poorer than for other BS tumors and malignant gliomas because the pons contains structures that control vital body functions like breathing, heart rate and arterial pressure [22]. Despite countless clinical trials of chemotherapy drugs and biological response modifiers, children with BS tumors still die, typically within 1 year after diagnosis [16, 20-24]. There is no effective treatment for recurrent/progressive BS tumors after initial RT. The average time to death after tumor recurrence is 3 months [25]. Various approaches, including RT and systemic drug therapy, tried for refractory and recurrent pediatric BS tumors are not standardized. RT is the only treatment option that has been shown to prolong survival in patients with recurrent/progressive DIPG [26, 27]. As more evidence is being accumulated about the safety of this approach for treating pediatric CNS tumors, re-irradiation is being increasingly used to manage recurrent/progressive DIPG in children [28-30].

$\mathrm{RT}$ is an important component of therapy for many pediatric CNS tumors, including DIPG. Re-irradiation is a safe option for managing recurrent ependymomas and medulloblastomas. It prolongs progression-free survival and, although there has been only 1 non-randomized phase 2 trial of this method, it has been shown to be a safe therapy for progressive DIPG $[26,29,30]$. Currently there are no treatment standards for re-
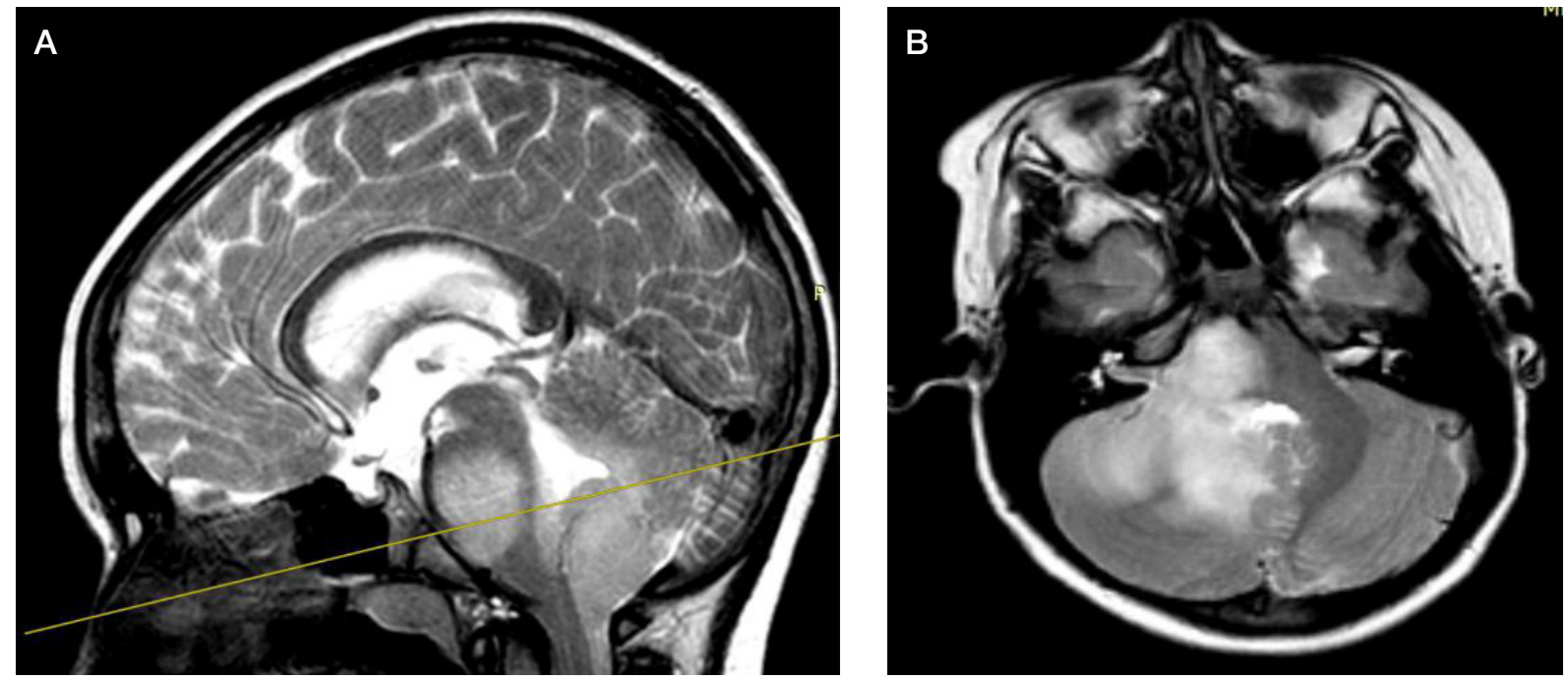

Fig. 1. Sagittal (A) and axial (B) MRI images of the patient's brain performed on July 10, 2019 before commencing RT 

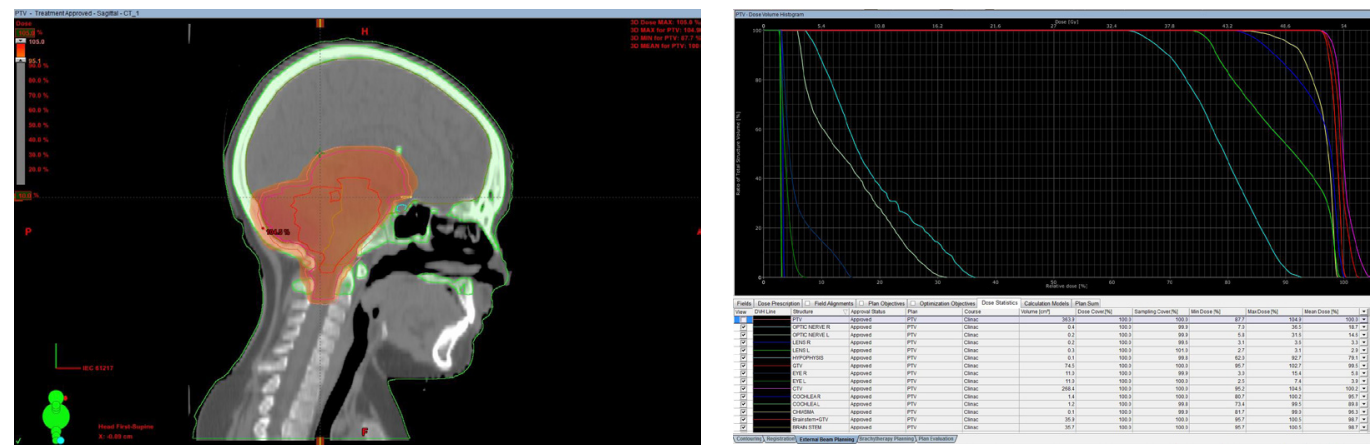

Fig. 2. Sagittal dose distribution of 3D conformal RT for the diffuse BS and a dose-volume histogram (DVH)

irradiation for pediatric CNS tumors. Most radiotherapists and pediatric oncologists consider a total dose of 20-36 Gy to be a therapeutic dose for children with BS tumors undergoing re-irradiation, but the number of sessions, the use of systemic drugs as a concomitant therapy and indications/ contraindications vary.

A few retrospective studies of re-irradiation have been conducted in small cohorts of pediatric patients with recurrent/ progressive DIPG.

In one of such studies, 5 children underwent re-irradiation and concomitant chemotherapy for progressive DIPG at the University of Texas MD Anderson Cancer Center. The following regimens were applied: 18 Gy in 1.8 Gy per fraction for 1 patient and 20 Gy in 2 Gy per fraction for 4 patients. Adverse events were minimal ( $\leq$ grade 2 RTOG). The median time to progression was 5 months [31]

An Italian research team studied the effects of radiation and concomitant therapy with nimotuzumab and vinorelbine in a phase 2 trial which included first-time patients with DIPG; relapsing patients were treated with re-irradiation. Tumor progression occurred in 20 patients; of them, 16 had a local recurrence. Focal re-irradiation of the locally progressing lesion (total dose of 19.8 Gy delivered in 1.8 Gy per fraction) was performed on 11 patients. Four of 5 other relapsing patients with metastatic tumor spread received focal re-irradiation for the primary lesion and its metastases. This approach was well tolerated, no unexpected adverse events or neurological status deterioration were observed. Survival after re-irradiation ranged from 6 weeks to 14 months and was 6 months on average [32].

Another European research team conducted a retrospective analysis of DIPG cases, including 31 patients who had received re-irradiation for the first tumor progression (total dose: 30 Gy delivered in 1.8 Gy per fraction); in addition to RT, some patients had received chemotherapy. Clinical improvement was observed in $77 \%$ patients, no life-threatening radiation toxicity was reported after re-irradiation. However, the study underscores that a combination of repeat $\mathrm{RT}$ and chemotherapy can produce lethal toxicity. Average survival in the study was 6.4 months after re-irradiation vs 3 months in the historical control group (no re-irradiation therapy) [15].

In another retrospective review published by Canadian researchers, re-irradiation was used on 16 patients with progressive DIPG. Focal re-irradiation therapy was delivered to 14 patients (total dose: 21.6-36 Gy). Two patients had to undergo whole-brain radiotherapy (total dose: 30.6 Gy) due to of metastasis. The applied RT doses varied, the total dose ranged from 12 to 36 Gy and was 24 Gy on average. The average re-irradiation dose per fraction was 2 Gy (1-9 Gy). The average time to progression after diagnosis was 10.5 months (4-37 months). One patient relapsed 6 months after re-irradiation and had to undergo one more course of reirradiation therapy (total dose: 21.6 Gy). One patient received concomitant therapy with bevacizumab. The rest were treated with RT only. Following the course of re-irradiation, 7 patients were prescribed chemotherapy with temozolomide, valproic acid, nimotuzumab, or bevacizumab. Re-irradiation was mostly well tolerated except for one patient who developed necrosis of the pons which caused cerebellar dysfunction and tetraparesis after exposure to the total dose of 30 Gy delivered in 3 Gy per fraction. Six patients did not require steroids; 4 patients discontinued steroids at the end of the re-irradiation course. The median follow-up time from diagnosis was 19.2 months; all
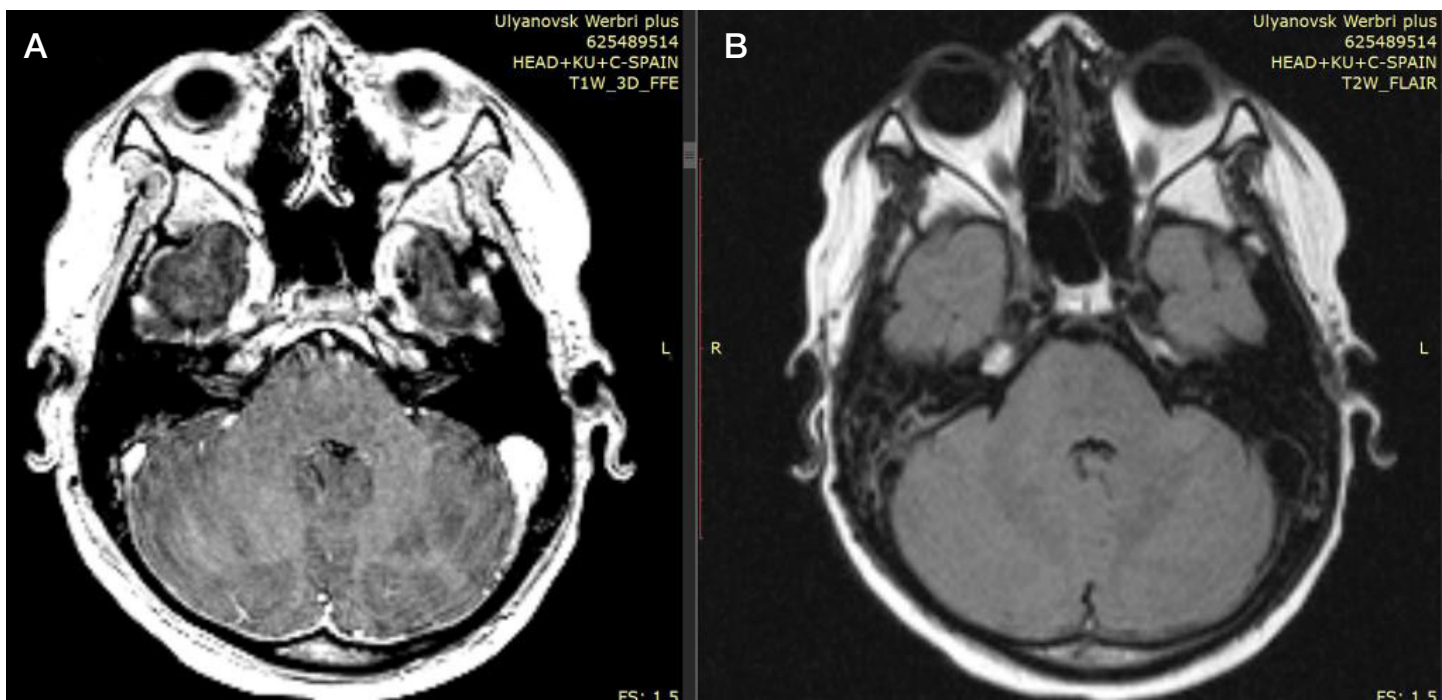

Fig. 3. Axial MRI images 1.5 months after RT completion (October 31, 2019): T1W (A) and T2W FLAIR (B) 

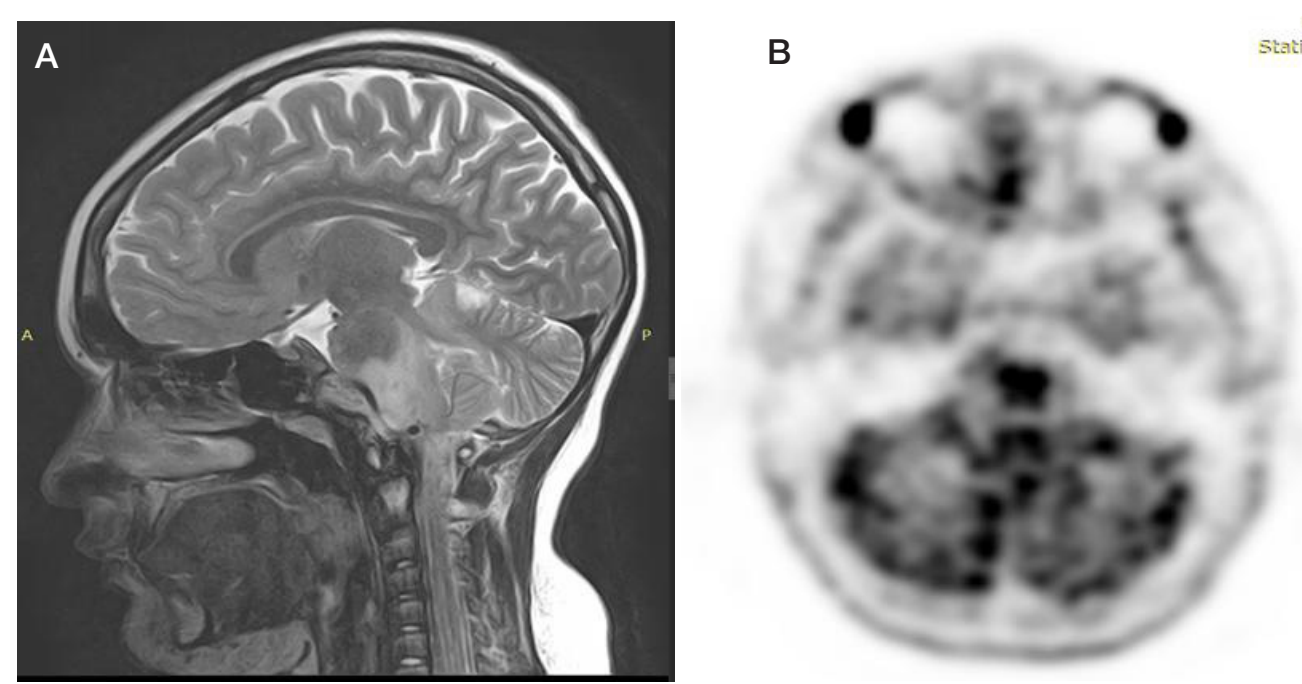

Fig. 4. A. Sagittal brain MRI image (December 8, 2020). B. Axial 11C-methionine PET/CT image (January 11, 2021)

the patients included in the study died. The median time from re-irradiation to death was 6.48 months (3.8-13.3 months) vs 3 months (3.8-13.9 months) in the historical control group of 46 patients with progressive DIPG (no re-irradiation; $p=0.0001$ ) [16].

Russian researchers have retrospectively analyzed the outcomes of re-irradiation among 20 children with different BS tumors undergoing treatment between 2001 and 2011. All of the children received re-irradiation after the initial $\mathrm{RT}$ (total dose: 50-55 Gy) course (combined with temozolomide in 7 cases). Re-irradiation was prescribed for clinically and radiographically confirmed tumor progression. Time between the end of the initial treatment and the beginning of re-irradiation therapy ranged from 5 to 32 months and was 12 months on average. Reirradiation was delivered in combination with adjuvant systemic chemotherapy: temozolomide (10 patients) and bevacizumab (3 patients). The total re-irradiation dose was < 30 Gy for 10 patients, 31-45 Gy for 9 patients and 50 Gy for 1 patient. While in treatment, 5 patients with radiographic signs of tumor destruction deteriorated and their therapy was terminated. The average survival time for those patients was 3.5 months. Other patients did not have signs of tumor destruction on MRI and their condition was improving. They were able to achieve complete or partial regression of neurological symptoms. In this subgroup, 93\% survived 6 months after re-irradiation, 53\% survived 1 year, 40\% survived 1.5 years, and 20\% survived 2 years. One patient stayed alive for 5 years after re-irradiation and died at the age of 13. Another patient developed symmetric necrotic lesions in the cerebellar hemispheres in the setting of persistent tumor growth detected on MRI 5 months after reirradiation (total dose: $50 \mathrm{~Gy}$ ) [2, 3, 8, 14].

Literature analysis and clinical experience show that pediatric diffuse BS tumors are currently incurable. The best effect that a combination of RT and chemotherapy can achieve is stabilization of tumor growth. Although there are no treatment standards regulating the use of re-irradiation therapy for pediatric CNS tumors, re-irradiation is an effective option that can sustain or improve the quality of life and prolong survival in children with diffuse BS tumors [34].

\section{CONCLUSION}

Modern RT, including proton re-irradiation, is an important component of combination therapy for diffuse BS tumor, especially in pediatric patients with complicated medical history.
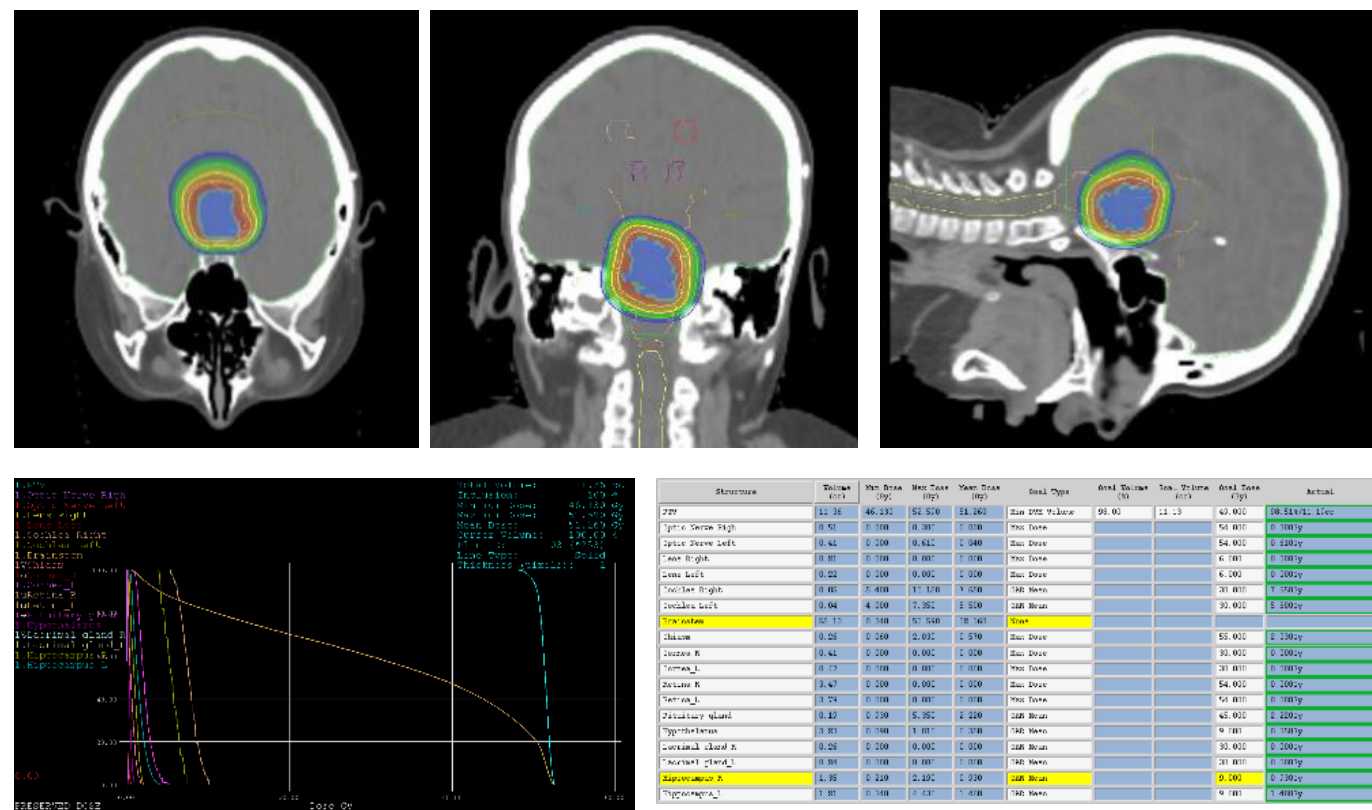

Fig. 5. Proton therapy dose distribution for the recurrent diffuse BS tumor and a dose-volume histogram 
1. Huhlaeva EA, Konovalov AN, Pronin IN, Kornienko VN, Gavryushin AV. Nejroradiologija i principy klassifikacii opuholej stvola golovnogo mozga. Medicinskaja vizualizacija. 2011; 6: 62-74. Russian.

2. Shherbenko OI, Parhomenko RA, Zelinskaya NI, Antonenko FF. Luchevaja i himioluchevaja terapija diffuzno rastushhih opuholej stvola mozga u detej: vlijaet li ad"juvantnaja himioterapija na rezul'taty? Onkopediatrija. 2015; 2 (3): 188-192. DOI 10.15690/ onco.v2.i3.1396. Russian.

3. Shcherbenko OI, Parkhomenko RA, Zelinskaya NI, Antonenko FF. The role of adjuvant chemotherapy for radiation therapy of diffusely growing tumors of the brain stem in children. The Russian Journal of Pediatric Hematology and Oncology. 2016; 5: 95.

4. Shcherbenko OI, Kumirova EV. K voprosu o vozmozhnostjah personalizacii primenenija himioterapii opuholej mozga na primere temozolomida. Voprosy gematologii/onkologii i immunopatologii v pediatrii. 2017; 16 (2): 84-90. DOI 10.24287/1726-1708-201716-2-84-90. Russian.

5. Guillamo JS, Doz F, Delattre JY. Brain stem gliomas. Current opinion in neurology. 2001; 14: 711-5.

6. Veldhuijzen van Zanten SEM, El-Khouly FE, Jansen MHA, Bakker DP, Aliaga ES, Haasbeek CJA. et al. A phase I/II study of gemcitabine during radiotherapy in children with newly diagnosed diffuse intrinsic pontine glioma. J Neurooncol. 2017; 135 (2): 307315. DOI 10.1007/s11060-017-2575-9.

7. Zalucky IV, Zhavrid EA, Mashevsky AA, Krutilina NI, Minailo II, Artemova NA, i dr. Luchevaja terapija opuholej central'noj nervnoj sistemy. Ukraiins'kij radiologichnij zhurnal. 2007; 2 (25): 150-153.

8. Shcherbenko OI, Parhomenko RA, Zelinskaya NI. Sovremennye vozmozhnosti konservativnogo lechenija neoperabel'nyh gliom golovnogo mozga u detej na primere diffuznorastushhih opuholej stvola mozga. Onkopediatrija. 2014; 3: 85. Russian.

9. Slobina EL, Antonenko FF, Zelinskaya NI. Primenenie tehnologii VMAT v lechenii opuholej u detej. Issledovanija i praktika v medicine. 2017; 4 (S1): 97. Russian.

10. Rusakova AD, Velcheva Al, Lushnikova NE. Novye metody luchevogo lechenija opuholej golovnogo mozga. Universitetskaja medicina Urala. 2021; 7 (2): 25-26. Russian.

11. Slobina E, Abbasova E, Zheludkova O, Smyslov A, Dykina A Vasilyev V, et al. PET-CT for Radiotherapy Planning of Pediatric Central Nervous System (CNS) Tumors. Book of Abstracts: International Conference on Clinical PET-CT and Molecular Imaging in the Era of Theranostics (IPET-2020), Vienna, Austria, 2020 24-26 Nov. Vienna, Austria: International Atomic Energy Agency; 2020. p. 131-132.

12. Slobina EL. Osnovy frakcionirovanija dozy luchevoj terapii. Onkologicheskij zhurnal. 2008; 2 (6): 173-86. Russian.

13. Arnone CM, Polito VA, Mastronuzzi A, Carai A, Diomedi FC Antonucci $L$, et al. Oncolytic adenovirus and gene therapy with EphA2- BiTE for the treatment of pediatric high-grade gliomas. Journal for ImmunoTherapy of Cancer. 2021; 9: e001930. DOI 10.1136/itc-2020-001930.

14. Shcherbenko OI, Zheludkova OG, Parkhomenko RA, Zelinskaya NI, Antonenko FF. Reirradiation treatment of diffuse brain stem tumors in children. The Russian Journal of Pediatric Hematology and Oncology. 2016; S: 97.

15. Janssens GO, Gandola L, Bolle S, Mandeville H, RamosAlbiac M, van Beek K, et al. Survival benefit for patients with diffuse intrinsic pontine glioma (DIPG) undergoing re-irradiation at first progression: A matched-cohort analysis on behalf of the SIOP-E-HGG/DIPG working group. Eur J Cancer. 2017; 73: 3847. DOI 10.1016/j.ejca.2016.12.007.

16. Lassaletta A, Strother D, Laperriere N, Hukin J, Vanan MI, Goddard K, et al. Reirradiation in patients with diffuse intrinsic pontine gliomas: The Canadian experience. Pediatr Blood Cancer. 2018; 65 (6): e26988. DOI: 10.1002/pbc.26988.

17. Klimanov VA, Samojlov AS, Udalov YuD, Gadzhinov AE, Peshkin YA. Fizika planirovanija protonnoj luchevoj terapii. Medicinskaja radiologija i radiacionnaja bezopasnost'. 2019; 64 (2): 23-32. DOI: 10.12737/article 5ca5e2677a1a06.60363700. Russian.

18. Shherbenko Ol. Uskorennye protony v lechenii opuholej CNS u detej: obzor literatury. Prakticheskaja onkologija. 2017; 18 (3): 298-306. Russian.

19. Udalov YuD, Kryuchko DS, Slobina EL, Stepanyuchenko EM, Danilova LA, Kiselev VA, Vasileva IV, avtory; Federal'noe gosudarstvennoe bjudzhetnoe uchrezhdenie «Federal'nyj nauchno-klinicheskij centr medicinskoj radiologii i onkologii» Federal'nogo mediko-biologicheskogo agentstva (FGBU FNKCRiO FMBA Rossii), pravoobladatel'. Baza dannyh pacientov, poluchavshih protonnuju terapiju po povodu onkologicheskih zabolevanij v sisteme FMBA Rossii. Svidetel'stvo o gosudarstvennoj registracii bazy dannyh RF \#2021620627. 02.04.2021. Russian.

20. Jansen MH, Veldhuijzen van Zanten SE, Sanchez AE, Heymans MW, Warmuth-Metz M, Hargrave D, et al. Survival prediction model of children with diffuse intrinsic pontine glioma based on clinical and radiological criteria. Neuro Oncol. 2015; 17 (1): 160-6. DOI: 10.1093/neuonc/nou104.

21. Pierre-Aurélien B, Alexandru S, Federico DR, Justyna K, Carmine M, Didier F. Diffuse intrinsic pontine glioma in children: document or treat? World Neurosurg. 2016; 93: 485.e11-485.e14.

22. Warren KE. Diffuse intrinsic pontine glioma: poised for progress. Front Oncol. 2012; 2: 205.

23. Sison J, Tran H, Margol A, Tiwari N, Garcia KM, Cotter J, et al. Palliative care options for a young adult patient with a diffuse intrinsic pontine glioma. Cureus. 2017; 9 (8): e1580.

24. Vanan MI, Eisenstat DD. DIPG in children - what can we learn from the past? Front Oncol. 2015; 5: 237.

25. Kline C, Liu SJ, Duriseti S, Banerjee A, Nicolaides Th, Raber Sh, et al. Reirradiation and PD-1 inhibition with nivolumab for the treatment of recurrent diffuse intrinsic pontine glioma: a singleinstitution experience. J Neurooncol. 2018; 140 (3): 629-38. DOI: 10.1007/s11060-018-2991-5.

26. Hargrave D, Bartels $U$, Bouffet E. Diffuse brainstem glioma in children: critical review of clinical trials. Lancet Oncol. 2006; 7 (3): 241-8.

27. Jalali R, Raut N, Arora B, Gupta T, Dutta D, Munshi A, et al. Prospective evaluation of radiotherapy with concurrent and adjuvant temozolomide in children with newly diagnosed diffuse intrinsic pontine glioma. Int J Radiat Oncol Biol Phys. 2010; 77 (1): 113-8. DOI: 10.1016/j.jijobp.2009.04.031.

28. Bouffet E, Hawkins CE, Ballourah W, Taylor MD, Bartels UK., Schoenhoff $N$, et al. Survival benefit for pediatric patients with recurrent ependymoma treated with reirradiation. Int $J$ Radiat Oncol Biol Phys. 2012; 83 (5): 1541-8. DOI: 10.1016/j. ijrobp.2011.10.039.

29. Tsang DS, Murray L, Ramaswamy V, Zapotocky M, Tabori U, Bartels $U$, et al. Craniospinal irradiation as part of re-irradiation for children with recurrent intracranial ependymoma. Neuro Oncol. 2019 Mar 18; 21 (4): 547-57. DOI: 10.1093/neuonc/noy191. PMID: 30452715; PMCID: PMC6422429.

30. Bakst RL, Dunkel IJ, Gilheeney S, Khakoo Y, Becher O, Souweidane $\mathrm{MM}$, et al. Reirradiation for recurrent medulloblastoma. Cancer. Nov 1 2011; 117 (21): 4977-82. DOI: 10.1002/cncr.26148. Epub 2011 Apr 14. PMID: 21495027.

31. Fontanilla HP, Pinnix CC, Ketonen LM, Woo SY, Vats TS, Rytting ME, et al. Palliative reirradiation for progressive diffuse intrinsic pontine glioma. Am J Clin Oncol. Feb 2012; 35 (1): 51-57. DOI: 10.1097/ COC.0b013e318201a2b7. PMID: 21297433.

32. Massimino M, Biassoni V, Miceli R, Schiavello E, Warmuth-Metz M, Modena $\mathrm{P}$, et al. Results of nimotuzumab and vinorelbine, radiation and re-irradiation for diffuse pontine glioma in childhood. J Neurooncol. Jun 2014; 118 (2): 305-12. DOI: 10.1007/s11060014-1428-z.

33. Massimino M, Biassoni V, Miceli R, Schiavello E, Warmuth-Metz M, Modena $\mathrm{P}$, et al. Correction to: Results of nimotuzumab and vinorelbine, radiation and re-irradiation for diffuse pontine glioma in childhood. Journal of Neuro-Oncology. 2018; 138 (3), 679-80. Available from: https://doi.org/10.1007/s11060-018-2893-6.

34. Cacciotti C, Liu KX, Haas-Kogan DA, Warren KE. Reirradiation practices for children with diffuse intrinsic pontine glioma. Neurooncol Pract. 2020 Oct 6; 8 (1): 68-74. DOI: 10.1093/nop/ npaa063. PMID: 33664971; PMCID: PMC7906270. 
1. Хухлаева Е. А., Коновалов А. Н., Пронин И. Н., Корниенко В. Н., Гаврюшин А. В. Нейрорадиология и принципы классификации опухолей ствола головного мозга. Медицинская визуализация. $2011 ; 6: 62-74$.

2. Щербенко О. И., Пархоменко Р. А., Зелинская Н. И., Антоненко Ф. Ф. Лучевая и химиолучевая терапия дифффузно растущих опухолей ствола мозга у детей: влияет ли адъювантная химиотерапия на результаты? Онкопедиатрия. 2015; 2 (3): 188-192. DOI 10.15690/onco.v2.i3.1396.

3. Shcherbenko OI, Parkhomenko RA, Zelinskaya NI, Antonenko FF. The role of adjuvant chemotherapy for radiation therapy of diffusely growing tumors of the brain stem in children. The Russian Journal of Pediatric Hematology and Oncology. 2016; 5: 95.

4. Щербенко О. И., Кумирова Э. В. К вопросу о возможностях персонализации применения химиотерапии опухолей мозга на примере темозоломида. Вопросы гематологии/онкологии и иммунопатологии в педиатрии. 2017; 16 (2): 84-90. DOI 10.24287/1726-1708-2017-16-2-84-90.

5. Guillamo JS, Doz F, Delattre JY. Brain stem gliomas. Current opinion in neurology. 2001; 14: 711-5.

6. Veldhuijzen van Zanten SEM, El-Khouly FE, Jansen MHA, Bakker DP, Aliaga ES, Haasbeek CJA. et al. A phase I/II study of gemcitabine during radiotherapy in children with newly diagnosed diffuse intrinsic pontine glioma. J Neurooncol. 2017; 135 (2): 307315. DOI 10.1007/s11060-017-2575-9.

7. Залуцкий И. В., Жаврид Э. А., Машевский А. А., Крутилина Н. И., Минайло И. И., Артемова Н. А. и др. Лучевая терапия опухолей центральной нервной системы. Український радіологічний журнал. 2007; 2 (25): 150-153.

8. Щербенко О. И., Пархоменко Р. А., Зелинская Н. И. Современные возможности консервативного лечения неоперабельных глиом головного мозга у детей на примере диффузнорастущих опухолей ствола мозга. Онкопедиатрия. 2014; 3: 85.

9. Слобина Е. Л., Антоненко Ф. Ф., Зелинская Н. И. Применение технологии VMAT в лечении опухолей у детей. Исследования и практика в медицине. 2017; 4 (S1): 97.

10. Русакова А. Д., Вельчева А. И., Лушникова Н. Е. Новые методы лучевого лечения опухолей головного мозга. Университетская медицина Урала. 2021; 7 (2): 25-26.

11. Slobina E, Abbasova E, Zheludkova O, Smyslov A, Dykina A, Vasilyev $\mathrm{V}$, et al. PET-CT for Radiotherapy Planning of Pediatric Central Nervous System (CNS) Tumors. Book of Abstracts: International Conference on Clinical PET-CT and Molecular Imaging in the Era of Theranostics (IPET-2020), Vienna, Austria, 2020 24-26 Nov. Vienna, Austria: International Atomic Energy Agency; 2020. p. 131-132.

12. Слобина Е. Л. Основы фракционирования дозы лучевой терапии. Онкологический журнал. 2008; 2 (6): 173-86.

13. Arnone CM, Polito VA, Mastronuzzi A, Carai A, Diomedi FC, Antonucci L, et al. Oncolytic adenovirus and gene therapy with EphA2- BiTE for the treatment of pediatric high-grade gliomas. Journal for ImmunoTherapy of Cancer. 2021; 9: e001930. DOI 10.1136/itc-2020-001930.

14. Shcherbenko OI, Zheludkova OG, Parkhomenko RA, Zelinskaya NI, Antonenko FF. Reirradiation treatment of diffuse brain stem tumors in children. The Russian Journal of Pediatric Hematology and Oncology. 2016; S: 97.

15. Janssens GO, Gandola L, Bolle S, Mandeville H, RamosAlbiac M, van Beek K, et al. Survival benefit for patients with diffuse intrinsic pontine glioma (DIPG) undergoing re-irradiation at first progression: A matched-cohort analysis on behalf of the SIOP-E-HGG/DIPG working group. Eur J Cancer. 2017; 73: 3847. DOI 10.1016/j.ejca.2016.12.007

16. Lassaletta A, Strother D, Laperriere N, Hukin J, Vanan MI, Goddard K, et al. Reirradiation in patients with diffuse intrinsic pontine gliomas: The Canadian experience. Pediatr Blood Cancer. 2018; 65 (6): e26988. DOI: 10.1002/pbc.26988.

17. Климанов В. А., Самойлов А. С., Удалов Ю. Д., Гаджинов А. Э., Пешкин Я. А. Физика планирования протонной лучевой терапии. Медицинская радиология и радиационная безопасность. 2019; 64 (2): 23-32. DOI: 10.12737/article_5ca 5e2677a1a06.60363700.

18. Щербенко О. И. Ускоренные протоны в лечении опухолей ЦНС у детей: обзор литературы. Практическая онкология. 2017; 18 (3): 298-306.

19. Удалов Ю. Д., Крючко Д. С., Слобина Е. Л., Степанюченко Е. М., Данилова Л. А., Киселев В. А., Васильева И. В., авторы; Федеральное государственное бюджетное учреждение «Федеральный научно-клинический центр медицинской радиологии и онкологии» Федерального медикобиологического агентства (ФГБУ ФНКЦРИО ФМБА России), правообладатель. База данных пациентов, получавших протонную терапию по поводу онкологических заболеваний в системе ФМБА России. Свидетельство о государственной регистрации базы данных РФ №2021620627. 02.04.2021.

20. Jansen MH, Veldhuijzen van Zanten SE, Sanchez AE, Heymans MW, Warmuth-Metz M, Hargrave D, et al. Survival prediction model of children with diffuse intrinsic pontine glioma based on clinical and radiological criteria. Neuro Oncol. 2015; 17 (1): 160-6. DOI: 10.1093/neuonc/nou104

21. Pierre-Aurélien B, Alexandru S, Federico DR, Justyna K, Carmine M, Didier F. Diffuse intrinsic pontine glioma in children: document or treat? World Neurosurg. 2016; 93: 485.e11-485.e14.

22. Warren KE. Diffuse intrinsic pontine glioma: poised for progress. Front Oncol. 2012; 2: 205.

23. Sison J, Tran H, Margol A, Tiwari N, Garcia KM, Cotter J, et al. Palliative care options for a young adult patient with a diffuse intrinsic pontine glioma. Cureus. 2017; 9 (8): e1580.

24. Vanan MI, Eisenstat DD. DIPG in children - what can we learn from the past? Front Oncol. 2015; 5: 237.

25. Kline C, Liu SJ, Duriseti S, Banerjee A, Nicolaides Th, Raber Sh, et al. Reirradiation and PD-1 inhibition with nivolumab for the treatment of recurrent diffuse intrinsic pontine glioma: a singleinstitution experience. J Neurooncol. 2018; 140 (3): 629-38. DOl: 10.1007/s11060-018-2991-5.

26. Hargrave D, Bartels U, Bouffet E. Diffuse brainstem glioma in children: critical review of clinical trials. Lancet Oncol. 2006; 7 (3): 241-8.

27. Jalali R, Raut N, Arora B, Gupta T, Dutta D, Munshi A, et al. Prospective evaluation of radiotherapy with concurrent and adjuvant temozolomide in children with newly diagnosed diffuse intrinsic pontine glioma. Int J Radiat Oncol Biol Phys. 2010; 77 (1): 113-8. DOI: 10.1016/j.ijrobp.2009.04.031.

28. Bouffet E, Hawkins CE, Ballourah W, Taylor MD, Bartels UK., Schoenhoff N, et al. Survival benefit for pediatric patients with recurrent ependymoma treated with reirradiation. Int J Radiat Oncol Biol Phys. 2012; 83 (5): 1541-8. DOl: 10.1016/j.jrobp.2011.10.039.

29. Tsang DS, Murray L, Ramaswamy V, Zapotocky M, Tabori U, Bartels $U$, et al. Craniospinal irradiation as part of re-irradiation for children with recurrent intracranial ependymoma. Neuro Oncol. 2019 Mar 18; 21 (4): 547-57. DOI: 10.1093/neuonc/noy191. PMID: 30452715; PMCID: PMC6422429.

30. Bakst RL, Dunkel IJ, Gilheeney S, Khakoo Y, Becher O, Souweidane $\mathrm{MM}$, et al. Reirradiation for recurrent medulloblastoma. Cancer. Nov 1 2011; 117 (21): 4977-82. DOI: 10.1002/cncr.26148. Epub 2011 Apr 14. PMID: 21495027

31. Fontanilla HP, Pinnix CC, Ketonen LM, Woo SY, Vats TS, Rytting ME, et al. Palliative reirradiation for progressive diffuse intrinsic pontine glioma. Am J Clin Oncol. Feb 2012; 35 (1): 51-57. DOI: 10.1097/ COC.0b013e318201a2b7. PMID: 21297433.

32. Massimino M, Biassoni V, Miceli R, Schiavello E, Warmuth-Metz M, Modena $\mathrm{P}$, et al. Results of nimotuzumab and vinorelbine, radiation and re-irradiation for diffuse pontine glioma in childhood. J Neurooncol. Jun 2014; 118 (2): 305-12. DOI: 10.1007/s11060-014-1428-z.

33. Massimino M, Biassoni V, Miceli R, Schiavello E, Warmuth-Metz M, Modena $\mathrm{P}$, et al. Correction to: Results of nimotuzumab and vinorelbine, radiation and re-irradiation for diffuse pontine glioma in childhood. Journal of Neuro-Oncology. 2018; 138 (3), 679-80. Available from: https://doi.org/10.1007/s11060-018-2893-6.

34. Cacciotti C, Liu KX, Haas-Kogan DA, Warren KE. Reirradiation practices for children with diffuse intrinsic pontine glioma. Neurooncol Pract. 2020 Oct 6; 8 (1): 68-74. DOI: 10.1093/nop/ npaa063. PMID: 33664971; PMCID: PMC7906270. 